\title{
DISTRIBUCIÓN DE PEQUEÑOS MAMÍFEROS EN LA CIUDAD DE SANTA FE, ARGENTINA
}

\author{
Sequeira, G. ${ }^{1,4}$; Vanasco, B. ${ }^{2}$; EnRIA, D. ${ }^{3}$;

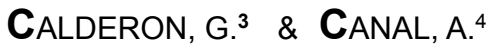

\begin{abstract}
RESUMEN
Este estudio se llevó a cabo con el objetivo de identificar las especies de micromamíferos y determinar su distribución en diferentes situaciones de urbanización en la ciudad de Santa Fe. Se utilizaron trampas Sherman y Tomahawk en cuatro ambientes en los que se dividió a la ciudad de acuerdo a características de población y ambiente. Las especies de animales fueron determinadas por sus características morfométricas y coloración. Se capturaron 246 micromamíferos desde el mes de enero de 1998 a diciembre de 1999, correspondiendo a especies de Rattus rattus ( $n=31$ ), Rattus norvergicus ( $n=25)$, Mus domesticus $(n=102)$, Akodon azarae $(n=30)$, Oligoryzomys flavescens $(n=19)$, Calomys laucha ( $n=2)$, Calomys musculinus ( $n=2)$, Holochilus brasiliensis $(n=1)$, Cavia aperea $(n=15)$, Didelphis albiventris $(n=14)$, Lutreolina crassicaudata $(n=2)$ y Monodelphis dimidiata $(n=2)$, estudiando su diversidad en los distintos ambientes. Se detectó la presencia de especies pertenecientes a la subfamilia Murinae en el ambiente urbano y la familia Cavidaee y subfamilia Sigmodontinae en los ambiente suburbano y semirural lo que evidencia un contacto estrecho de especies de vida silvestre con áreas pobladas muy relacionadas con la vida urbana. La zona suburbana presentó la mayor riqueza y diversidad $\left(\mathrm{H}^{1}\right)$, mientras que la zona urbana la menor riqueza y menor uniformidad. Las especies de micromamíferos capturados y su distribución alertan sobre el riesgo de aparición de enfermedades emergentes humanas.
\end{abstract}

Palabras clave: micromamíferos, diversidad, enfermedades emergentes, zoonosis.

\section{SUMMARY}

\section{Small-mammals distribution in Santa Fe city, Argentina.}

The aim of this study was to identify the different small-mammal species and to determine their distribution in Santa Fe city, Argentina. Animals were trapped in four differents sites according to populations and environment characteristics, using Sherman and Tomahawk traps. They were classify by morphometric and reproductive characteristics. Two hundred and forty six small-mammals were captured from January 1998 to December 1999. Animals belonged to species Rattus rattus ( $n=31)$,

1.- Municipalidad de la ciudad de Santa Fe. Av. Perón 3575. 3000, Santa Fe. E-mail: sequeira@unl.edu.ar

2.- Instituto Nacional de Enfermedades Respiratorias "E. Coni” (INER). Blas Parera 8260. 3000, Santa

Fe. E-mail: jlotters@fbcb.unl.edu.ar

3.- Instituto Nacional de Enfermedades Virales Humanas “J. Maiztegui” (INEVH). Monteagudo 2510.

2700, Pergamino, provincia de Buenos Aires. E-mail: gladys@inevh.sld.ar

4.- Facultad de Ciencias Veterinarias. UNL. Kreder 2805. 3080, Esperanza.

Manuscrito recibido el 21 de agosto de 2002 y aceptado para su publicación el 2 de abril de 2003. 
Rattus norvergicus ( $\mathrm{n}=25)$, Mus domesticus $(\mathrm{n}=102)$, Akodon azarae $(\mathrm{n}=30)$, Oligoryzomys flavescens ( $\mathrm{n}=19)$, Calomys laucha $(\mathrm{n}=2)$, Calomys musculinus $(\mathrm{n}=2)$, Holochilus brasiliensis $(\mathrm{n}=1)$, Cavia aperea $(n=15)$, Didelphis albiventris $(n=14)$, Lutreolina crassicaudata $(n=2)$ and Monodelphis dimidiata $(\mathrm{n}=2)$. In urban areas species of subfamily Murinae were detected. The finding of an great number of species of family Caviidae and subfamily Sigmodontinae in suburban and in semi-rural areas involved a close contact between wildlife small-mammals and human life. The suburban zone displayed the greater wealth and diversity (H1), whereas the urban zone the smaller wealth and minor uniformity. The species collected and their distribution, alert on the risk of occurence of emerging zoonotic diseases.

Key words: small-mammals, animals belonged, emerging diseases, zoonotic. 